\title{
Flooding Reduces Gas Exchange and Growth in Snap Bean
}

\author{
Bharat P. Singh, Kevin A. Tucker, James D. Sutton, and \\ Harbans L. Bhardwaj \\ Agricultural Research Station, Fort Valley State College, Fort Valley, \\ GA 31030-3298
}

Additional index words. Phaseolus vulgaris, net photosynthesis, stomatal conductance, water potential

\begin{abstract}
This study was conducted to determine the effect of various flooding durations on the growth, water relations, and photosynthesis of the snap bean (Phaseolus vulgaris L.). Greenhouse-grown plants of CV. Blue Lake 274 were flooded for 0 (control), 1, 3, 5, or 7 days. Leaf water potential $(\psi)$, stomatal conductance $\left(g_{s}\right)$, transpiration (E), and net photosynthesis (Pn) were measured at the completion of the flooding period and after recovery for 7 days. Root, stem, and leaf dry weights were recorded after plants were allowed to recover from the flooding stress for 7 days. The values for $\psi, g_{s}, E$, and Pn decreased quadratically with the increase in the duration of flooding. The Pn of plants flooded for 1 day was $17 \%$ lower than that of the control and it reached near zero in plants flooded for 7 days. The decrease in Pn after 1 day of flooding was not associated with $\psi$ or $\mathrm{g}_{\mathrm{s}}$; however, for longer duration of flooding, Pn decline coincided with the decline in $\mathrm{g}_{\mathrm{s}}$. A week after the cessation of flooding, the level of recovery in $\psi, \mathbf{E}$, and Pn was linear and that in $g_{s}$ quadratic to the duration of prior stress experienced by the plant. However, after recovering for 7 days, none of the flooded plants regained gas exchange activities at par with the control. The relationship of stem dry weight to duration of flooding was linear, while a quadratic model provided the best fit for the regression of root and leaf dry weight on the number of days of flooding. Overall, even 1 day of flooding reduces photosynthesis in snap bean and causes a decrease in dry weight of the plant. the extent of decrease in both increasing with the duration of flooding.
\end{abstract}

Flooding of vegetable fields may last from a few hours to several days, depending on the severity of the contributing factors. The extent of injury to a crop depends on its susceptibility to and the duration of flooding (Kramer, 1951). The affected plants exhibit reduced root growth, a slower rate of dry matter accumulation, and low or no yield (Hozumi, 1966; Inden, 1956; Lopez and del Rosario, 1983; Trought and Drew, 1980; Van't Woudt and Hagen, 1957). Flooding results in a partial to complete closure of stomata (Jackson et al., 1978; Sojka and Stolzy, 1980). Bradford and Hsiao (1982) suggested that roots influenced the stomatal behavior of flooded tomato (Lycopersicon esculentum L.) plants. The response of snap bean to flooding is not well-understood. The results of preliminary work by Singh and Tucker (1988) and Lakitan and Wolfe (1988a, $1988 \mathrm{~b}$ ) indicate that flooding reduces growth and gas exchange in snap bean. Our study was conducted to determine the effects of flooding duration on $\mathrm{g}, \mathrm{E}, \psi, \mathrm{Pn}$, and subsequent root, stem, and leaf growth in snap bean.

\footnotetext{
Received for publication 29 Jan. 1990. The cost of publishing this paper was defrayed in part by the payment of page charges. Under postal regulations, this paper therefore must be hereby marked advertisement solely to indicate this fact.
}

Abbreviations: E, transpiration; $\mathrm{g}_{\mathrm{s}}$, stomatal conductance; Pn, net photosynthesis; $\psi$, leaf water potential.
The first experiment was planted in a greenhouse at Fort Valley, Ga., on 8 Mar. 1988. The greenhouse was held at $26 \pm 3 \mathrm{C} /$ $20 \pm 2 \mathrm{C}$, day/night, respectively. Three seeds of 'Blue Lake 274' snap bean were planted in each of 75 three-liter pots filled with Dothan sandy loam soil (fine loamy, siliceous, thermic, Plinthic Paleudtdt). Seedlings were thinned to one plant per pot upon emergence. Plants were watered daily and fertilized twice a week by mixing $20 \mathrm{~N}-10 \mathrm{P}-20 \mathrm{~K}$ soluble fertilizer in the irrigation water until the start of flooding treatments. The experimental treatments consisted of five flooding durations: 0 (control, T0), 1 (T1), 3 (T3), 5 (T5), and 7 days (T7). Each flooding treatment was applied to 15 pots. The flooding treatments were started 27 days after planting. The flooding conditions were created by placing the 3-liter pots with plants into plastic-lined 4-liter pots filled with water. At the completion of flooding, experimental pots were removed from the plastic-lined pots and allowed to drain. The pots in each flooding treatment were allowed to recover from flooding stress for 7 days. The flooding stress was started with $\mathrm{T} 7$ plants followed by $\mathrm{T} 5$, $\mathrm{T} 3$, and $\mathrm{T} 1$ treatments at 2-day intervals. This enabled all flooding treatments to finish simultaneously. The pots were placed on greenhouse benches in a completely randomized design. Out of 15 pots per flooding treatment, five were used to measure gas exchange and plant growth. The remaining 10 pots were used for $\psi$ measurements. Since $\psi$ measurements involved the destructive separation of leaves from plants, data were recorded from five pots at the completion of flooding treatments and on the remaining five pots upon 7 days of recovery.

The gas exchange measurements were recorded twice, first upon the completion of flooding and after the 7 days of recovery. After the second gas exchange measurements, the plants were harvested for vegetative growth measurements that consisted of leaf count and area, root volume, and root, stem, and leaf dry weight on a per-plant basis, The roots were separated from the soil by gently washing the soil core with water. The root volume was determined by immersing roots into a partially filled graduated cylinder and then recording the resulting water displacement. All plant parts were dried at $65 \mathrm{C}$ for 5 days before their dry weights were recorded.

The measurements for $\mathrm{g}_{\mathrm{s}}, \mathrm{E}$, and Pn were made from the two uppermost fully expanded leaves per plant using a portable leaf chamber analyzer (Analytical Development, Huddleston, England). Data collection was carried out in the morning hours with photon flux densities of 1040 to $1090 \mu \mathrm{mol} \cdot \mathrm{s}^{-1} \cdot \mathrm{m}^{-2}$. Air flow through the system was 400 $\mathrm{ml} \cdot \mathrm{min}^{-1}$. The leaf area was measured with an automatic leaf area meter (Model AAM5, Hayashi Denko Co., Tokyo). A pressure bomb (Model 3005, Soil Moisture Equipment Corp., Santa Barbara, Calif.) was used to measure $\psi$ of the two uppermost fully expanded leaves per plant.

A second experiment was planted on 23 Mar. 1989. The experimental procedures and data recording used in this experiment were identical to those in the experiment conducted during 1988. The experiment $x$ treatment interaction was not significant; therefore, data from both experiments were combined and analyzed using regression and correlation analyses.

The values for $\psi, g_{s}, E$, and Pn decreased quadratically with the increase in the duration of flooding (Table 1). The $\psi$ of $\mathrm{T} 0$ plants was more than three times that of T3 plants. Plants from $\mathrm{T} 1$ had $17.4 \%$ higher $\mathrm{g}_{\mathrm{s}}$ and $23.5 \%$ higher $\mathrm{E}$ than those from T0. However, $g_{s}$ and $\mathrm{E}$ of $\mathrm{T} 3$ plants declined to 0.02 and $0.87 \mathrm{mmol} \cdot \mathrm{m}^{-2} \cdot \mathrm{s}^{-1}$ respectively, as compared to 397 and $7.10 \mathrm{mmol} \cdot \mathrm{m}^{-2} \cdot \mathrm{s}^{-1}$ for T0 plants. The Pn of T1 plants was $17 \%$ lower than for T0 plants. Three days of flooding lowered Pn by $84 \%$, and T7 plants ceased photosynthesizing. Pezeshki and Sundstrom (1988) observed that $\mathrm{g}_{\mathrm{s}}$ in pepper (Capsicum annum L.) declined by $88 \%$ after 2 days of flooding. Brix (1962) and Pezeshki and Sundstrom (1988) have reported a rapid decline in Pn due to flooding in tomato and pepper, respectively.

A week after the cessation of flooding, the level of recovery in $\psi, \mathrm{E}$, and Pn was linear and that in g quadratic in relation to the duration of the prior stress experienced by the plant. However, after recovering for 7 days, none of the flooded plants regained gas exchange activities at par with the control.

The relationship of stem dry weight, leaf count, and leaf area to the various durations 
Table 1. $\psi, \mathrm{g}_{\mathrm{s}}, \mathrm{E}$, and $\mathrm{Pn}$ of snap bean upon completion of flooding treatments and after recovering for 7 days.

\begin{tabular}{|c|c|c|c|c|c|c|c|c|}
\hline \multirow{2}{*}{$\begin{array}{l}\text { Flooding } \\
\text { duration } \\
\text { (days) }\end{array}$} & \multicolumn{2}{|c|}{$\psi(\mathrm{MPa})$} & \multicolumn{2}{|c|}{$\mathrm{g}_{\mathrm{s}}\left(\mathrm{mmol} \cdot \mathrm{m}^{-2} \cdot \mathrm{s}^{-1}\right)$} & \multicolumn{2}{|c|}{$\mathrm{E}\left(\mathrm{mmol} \cdot \mathrm{m}^{-2} \cdot \mathrm{s}^{-1}\right)$} & \multicolumn{2}{|c|}{$\operatorname{Pn}\left(\mu \mathrm{mol} \mathrm{CO} \mathrm{CO}_{2} / \mathrm{m}^{2}\right.$ per sec $)$} \\
\hline & $\begin{array}{l}\text { Completion of } \\
\text { flooding }\end{array}$ & $\begin{array}{l}\text { After } \\
\text { recovery }\end{array}$ & $\begin{array}{l}\text { Completion of } \\
\text { flooding }\end{array}$ & $\begin{array}{l}\text { After } \\
\text { recovery }\end{array}$ & $\begin{array}{l}\text { Completion of } \\
\text { flooding }\end{array}$ & $\begin{array}{l}\text { After } \\
\text { recovery }\end{array}$ & $\begin{array}{l}\text { Completion of } \\
\text { flooding }\end{array}$ & $\begin{array}{l}\text { After } \\
\text { recovery }\end{array}$ \\
\hline 0 (control) & -0.260 & -0.358 & 397.3 & 517.5 & 7.10 & 8.89 & 13.72 & 15.90 \\
\hline 1 & -0.342 & -0.332 & 466.6 & 302.7 & 8.77 & 7.10 & 11.38 & 10.95 \\
\hline 3 & -0.846 & -0.354 & 0.02 & 283.1 & 0.87 & 6.23 & 2.78 & 11.53 \\
\hline 5 & -0.610 & -0.460 & 0.02 & 118.5 & 0.54 & 3.89 & 1.80 & 5.67 \\
\hline 7 & -0.682 & -0.460 & 4.4 & 105.3 & 0.23 & 3.83 & 0.10 & 5.55 \\
\hline Significance $^{x}$ & $Q^{* y}$ & $L^{* * x}$ & $Q^{* * w}$ & $\mathrm{Q}^{* v}$ & $Q^{* * u}$ & $\mathrm{~L}^{* * 1}$ & $Q^{* * s}$ & $L^{* * r}$ \\
\hline
\end{tabular}

${ }^{2} \mathrm{Q}=$ quadratic, $\mathrm{L}=$ linear.

$\mathrm{y}_{\mathrm{Y}}=-0.24-0.22 \mathrm{x}+0.02 \mathrm{x}^{2}, R^{2}=0.42$.

${ }^{x} Y=-0.33-0.02 x, R^{2}=0.32$.

${ }^{w} \mathrm{Y}=478.89-176.23 \mathrm{x}+15.41 \mathrm{x}^{2}, R^{2}=0.60$.

${ }^{\vee} \mathrm{Y}=477.10-104.76 \mathrm{x}+7.35 \mathrm{x}^{2}, R^{2}=0.67$

uY $=8.60-2.73 \mathrm{x}+0.22 \mathrm{x}^{2}, R^{2}=0.76$.

$\mathrm{Y} Y=8.41-0.73 \mathrm{x}, R^{2}=0.60$.

sY $=14.23-4.39 \mathrm{x}+0.34 \mathrm{X}^{2}, R^{2}=0.90$.

$\mathrm{r} Y=14.41-1.40 \mathrm{x}, R^{2}=0.55$

*,**Significant at $P=0.05$ or 0.01 , respectively.

Table 2. Characteristics of snap bean plants after recovering for 7 days following being flooded for various periods.

\begin{tabular}{lcccccc}
\hline \hline $\begin{array}{l}\text { Flooding } \\
\text { duration } \\
\text { (days) }\end{array}$ & $\begin{array}{c}\text { Root } \\
\text { dry wt } \\
\text { (g/plant) }\end{array}$ & $\begin{array}{c}\text { Root } \\
\text { vol. } \\
\text { (ml/plant) }\end{array}$ & $\begin{array}{c}\text { Stem } \\
\text { dry wt } \\
\text { (g/plant) }\end{array}$ & $\begin{array}{c}\text { Leaves } \\
\text { (no./plant) }\end{array}$ & $\begin{array}{c}\text { Leaf } \\
\text { area } \\
\left(\mathrm{cm}^{2} / \text { plant }\right)\end{array}$ & $\begin{array}{c}\text { Leaf } \\
\text { dry wt } \\
\text { (g/plant) }\end{array}$ \\
\hline 0 (control) & 2.63 & 26.8 & 1.17 & 18.0 & 508 & 2.19 \\
1 & 1.29 & 12.6 & 1.29 & 18.8 & 508 & 1.63 \\
3 & 1.09 & 11.2 & 0.97 & 17.2 & 408 & 1.33 \\
5 & 0.83 & 8.0 & 0.65 & 10.2 & 223 & 0.87 \\
7 & 0.83 & 8.2 & 0.71 & 11.8 & 243 & 0.91 \\
Significance $^{z}$ & $\mathrm{Q}^{* * \mathrm{y}}$ & $\mathrm{Q}^{* * x}$ & $\mathrm{~L}^{* * \mathrm{w}}$ & $\mathrm{L}^{* * \mathrm{v}}$ & $\mathrm{L}^{* * \mathrm{u}}$ & $\mathrm{Q}^{* * 1}$ \\
\hline
\end{tabular}

${ }^{2} \mathrm{Q}=$ quadratic, $\mathrm{L}=$ lincar.

$\mathrm{y} Y=2.34-0.64 \mathrm{x}+0.06 \mathrm{x}^{2}, R^{2}=0.58$.

$x Y=23.65-6.58 \mathrm{x}+0.64 \mathrm{x}^{2}, R^{2}=0.68$.

${ }^{\mathrm{w}} \mathrm{Y}=1.24-0.09 \mathrm{x}, R^{2}=0.48$.

${ }^{v} Y=19.02-1.20 \mathrm{x}, R^{2}=0.53$.

"Y $-524.23-45.71 \mathrm{x}, R^{2}=0.72$.

$' \mathrm{Y}=2.13-0.40 \mathrm{x}+0.03 \mathrm{x}^{2}, R^{2}=0.73$.

** Significant at $P=0.01$.

of flooding was linear (Table 2). A quadratic model provided best fit for the regression of root and leaf dry weight and root volume on the number of days of flooding. Root volume and root dry weight of T1 plants was reduced by $>50 \%$ relative to T0 plants. We noted that stressed plants had considerably fewer lateral roots than the control. The lower leaf count and leaf area in plants subjected to flooding was primarily due to the senescence of the large lower leaves.

The $\mathrm{g}_{\mathrm{s}}$ and $\psi$ exhibited a positive correlation $(r=0.62)$, indicating that $38 \%\left(r^{2}=\right.$ 0.38 ) of the sum of the squares of $g_{s}$ can be attributed to variation in $\psi$ (Steel and Torrie, 1980). However, the magnitude of the coefficient of determination suggests that other factors, along with $\psi$, may be involved in controlling stomatal closure. Jackson and Hall (1987) have attributed early stomata] closure (after $24 \mathrm{hr}$ ) in pea (Pisum sativum L.) to increases in the concentration of endogenous abscisic acid in the leaf due to inhibition of its transport to flooded roots. The correlation coefficient of 0.94 between $g_{s}$ and $E$ indicated that $\mathrm{E}$ of flooded plants declined mainly due to stomatal closure. Bradford and Hsiao (1982) and Jackson and Hall (1987) have reported stomatal closure as the cause of $\mathrm{E}$ reduction in tomato and pea, respectively.
The correlation coefficient between $g_{s}$ and Pn was 0.84 . However, as noted earlier, after 1 day of flooding, while $\mathrm{g}_{\mathrm{s}}$ increased, $\mathrm{Pn}$ decreased. Apparently, the Pn decline after 1 day of flooding was independent of the $g$ reduction and the association of Pn with the decrease in $g_{s}$ was manifested at a later time. Additional study would be required to determine the relative magnitude of stomatal vs. nonstomatal factors controlling Pn under flooded conditions.

We conclude from this study that flooding affects Pn before $g_{s}$ or $\psi$ in snap bean. However, as duration of flooding increases, Pn decline becomes closely linked with decline in $g$. The plants recover slowly after flooding-stress removal; $\psi$ and gas exchanges of stressed plants remain significantly lower than the control even after recovering for 7 days. Flooding decreases root and shoot growth in snap bean.

\section{Literature Cited}

Bradford, K.J. and T.C. Hsiao. 1982. Stomatal behavior and water relations of waterlogged tomato plants. Plant Physiol. 70:1508-1513.

Brix, H. 1962. The effect of water stress on the rates of photosynthesis and respiration in tomato plant and loblolly pine seedlings. Physiol. Plant. 15:10-20.
Hozumi, K. 1966. Water tolerance of vegetable crops (in Japanese). Nogyo Gijyutsu 26:352357.

Inden, T. 1956. On the physiology of the roots of vegetable crops. IV. Effects of oxygen pressure in the soil atmosphere on the growth and uptake of nutrients in tomatoes. cucumbers and egg plants (in Japanese, English summary). J. Hort. Assn. Jpn. 25:85-93.

Jackson, M.B., K. Gales, and D.J. Campbell. 1978. Effect of waterlogged soil conditions on the production of ethylene and on water relationships in tomato plants. J. Expt. Bot. 29:183193.

Jackson, M.B. and K.C. Hall. 1987. Early stomatal closure in waterlogged pea plants as mediated by abscisic acid in the absence of foliar water deficits. Plant Cell Env. 10:121-130.

Kramer, P.J. 1951. Causes of injury to plants resulting from flooding of the soil. Plant Physiol. 26:722-736.

Lakitan, B. and D.W. Wolfe. 1988a. Yield and growth suppressions in flooded snap bean (Phaseolus vulgaris L.) as related to plant age. HortScience 23:799. (Abstr.)

Lakitan, B. and D.W. Wolfe. 1988b. Stomatal and photosynthetic responses of Phaseolus vulgaris cultivars to flooding. HortScience 23:800. (Abstr.)

Lopez, M.V. and D.A. del Rosario. 1983. Performance of tomatoes under waterlogged condition. Phillipp. J. Crop Sci. 8:75-80.

Pezeshki, S.R. and F.J, Sundstrom. 1988. Effect of soil anaerobiosis on photosynthesis of Capsicum annum L. Scientia Hort. 35:27-36.

Singh, B.P. and K. Tucker. 1988. Effect of waterlogging durations on performance of snap bean. Amer. Soc. Agron. p. 118. (Abstr.)

Sojka, R.E. and L.H. Stolzy. 1980. Soil-oxygen effects on stomatal response. Soil Sci. 130:350358.

Steel, R.G.D. and J.H. Torrie. 1980. Principles and procedures of statistics. McGraw-Hill, New York.

Trought, M.C.T. and M.C. Drew. 1980. The development of waterlogging damage in wheat seedlings (Triticum aestivurn L.). I. Shoot and root growth in relation to changes in the concentration of dissolved gases and solutes in the soil solution. Plant and Soil 54:77-94.

Van't Woudt and Hagan, R.M. 1957. Crop responses at excessively high moisture levels, $\mathrm{p}$. 514-578. In: J.N. Luthin (ed.). Drainage of agricultural lands. Agron. Monogr. 7. Amer. Soc. Agron. Madison, Wis. 